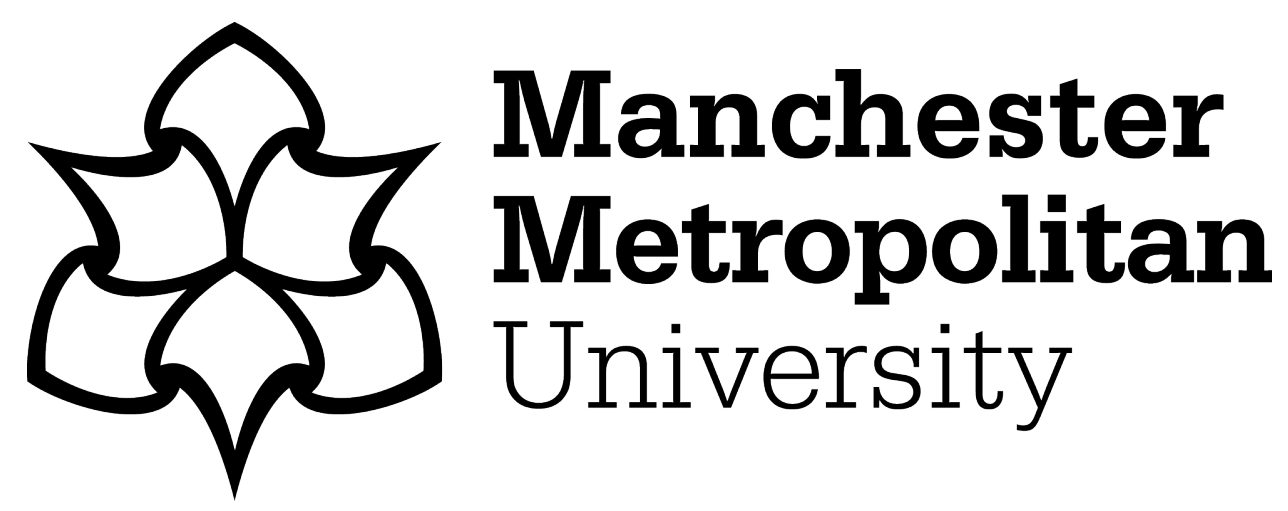

Mole, SE, Anderson, G, Band, HA, Berkovic, SF, Cooper, JD, Kleine Holthaus, SM, McKay, TR, Medina, DL, Rahim, AA, Schulz, A and Smith, AJ (2019) Clinical challenges and future therapeutic approaches for neuronal ceroid lipofuscinosis. The Lancet Neurology, 18 (1). pp. 107-116. ISSN 1474-4422

Downloaded from: https://e-space.mmu.ac.uk/625388/

Version: Accepted Version

Publisher: Elsevier

DOI: https://doi.org/10.1016/S1474-4422(18)30368-5

Usage rights: Creative Commons: Attribution-Noncommercial-No Derivative Works 4.0

Please cite the published version 


\title{
Clinical challenges and future therapeutic approaches for neuronal ceroid lipofuscinosis
}

\author{
Sara E Mole, Glenn Anderson, Heather A Band, Samuel F Berkovic, Jonathan D Cooper, Sophia-Martha kleine Holthaus, Tristan R McKay, \\ Diego L Medina, Ahad A Rahim, Angela Schulz, AlexanderJ Smith
}

Treatment of the neuronal ceroid lipofuscinoses, also known as Batten disease, is at the start of a new era because of diagnostic and therapeutic advances relevant to this group of inherited neurodegenerative and life-limiting disorders that affect children. Diagnosis has improved with the use of comprehensive DNA-based tests that simultaneously screen for many genes. The identification of disease-causing mutations in 13 genes provides a basis for understanding the molecular mechanisms underlying neuronal ceroid lipofuscinoses, and for the development of targeted therapies. These targeted therapies include enzyme replacement therapies, gene therapies targeting the brain and the eye, cell therapies, and pharmacological drugs that could modulate defective molecular pathways. Such therapeutic developments have the potential to enable earlier diagnosis and better targeted therapeutic management. The first approved treatment is an intracerebroventricularly administered enzyme for neuronal ceroid lipofuscinosis type 2 disease that delays symptom progression. Efforts are underway to make similar progress for other forms of the disorder.

\section{Introduction}

The neuronal ceroid lipofuscinoses (NCLs), also known as Batten disease, are a group of monogenic inherited neurodegenerative disorders that mostly present in the first decade of life. ${ }^{1}$ They share a broadly similar clinical presentation characterised by seizures, visual failure, and a progressive decline in cognitive and motor abilities due to progressive neuronal death. However, these disorders also show variation, most notably in the age of onset, rate of disease progression, and first symptoms. ${ }^{1}$ Regardless, all forms of NCLs are fatal and no curative treatments are available.

Pathologically, these disorders are profoundly neurodegenerative, and share a common hallmark of accumulation of autofluorescent material in lysosomes, called ceroid and lipofuscin, that has a typical ultrastructural appearance under electron microscopy but does not appear to relate directly to neuron loss. ${ }^{2}$ Although the precise underlying mechanisms remain elusive, disease-causing mutations have been revealed in 13 different genes: PPT1, TPP1, DNAJC5, CLN3, CLN5, CLN6, MFSD8, CLN8, CTSD, GRN, ATP13A2, CTSF, and KCDT7., ${ }^{3,4}$ The increasing implementation of next generation sequencing panels and exome sequencing as essential diagnostic tools leads to more diagnoses of patients with NCL, including those varying from the typically recognised phenotypes due to so-called milder mutations. This has necessitated a change in disease nomenclature based on the gene defect augmented with age of presentation. ${ }^{4}$

There has been an emphasis on understanding the staging of these disorders and their molecular pathways, and advancing experimental therapies such as enzyme replacement and gene therapy in animal models, ${ }^{5-8}$ together with the establishment of patient registries ${ }^{9,10}$ and disease rating scales. ${ }^{11,12}$ These efforts have culminated in the approval by the US Food and Drug Administration (FDA) and the European Medicines Agency (EMA) of the first treatment for a NCL disorder: enzyme replacement therapy for neuronal ceroid lipofuscinosis type 2 (CLN2) disease. ${ }^{13,14}$ Much preclinical work followed by clinical trials is required before treatment is available for all forms of NCLs. This Review provides an update on clinical features, genotype-phenotype correlations, pathology, and discusses the most promising therapeutic approaches of NCLs.

\section{Clinical characteristics}

All patients with NCLs, except for those with a rare congenital form (neuronal ceroid lipofuscinosis type 10 [CLN10] disease), have a normal psychomotor development before onset of first symptoms. ${ }^{1}$ Age at disease onset is in childhood for most patients, but for some can be as late as 60 years or older (table 1). The main symptoms are a combination of at least two of the following: dementia, epilepsy, motor deterioration, and visual loss. ${ }^{1}$ The order in which symptoms occur varies and depends on the combination of the underlying mutations, which can affect age at onset and disease phenotype. ${ }^{1}$ The number of phenotypes for NCL diseases is growing and the widest age range of onset is for those NCLs arising from lysosomal enzyme deficiencies (table 1). ${ }^{3}$ Increasing knowledge about the natural history of the different forms of NCLs has shown that for some genes the phenotype severity can vary substantially even between siblings, as in juvenile neuronal ceroid lipofuscinosis type 3 (CLN3) disease. ${ }^{16}$ Symptoms can also be outside the CNS. For example, cardiac involvement has been reported in adolescent and adult patients with CLN3 disease $\mathrm{e}^{17,18}$ and can be treated (eg, fitting of a pacemaker has improved a patient's psychomotor abilities). ${ }^{16}$

First symptoms in classic infantile (age of onset 6-24 months) and late-infantile (age of onset 2-5 years) phenotypes are slowing of psychomotor development, quickly followed by standstill, then progressive loss of acquired psychomotor abilities and onset of epilepsy, and lastly followed by vision loss. ${ }^{1}$ This regression is often mistaken for a side-effect of antiepileptic drugs, delaying diagnosis. By contrast, first symptoms in the
Lancet Neurol 2018; 18: 107-16 Published Online November 20, 2018 http://dx.doi.org/10.1016/ S1474-4422(18)30368-5

Medical Research Council Laboratory for Molecular Cell Biology and UCL Great Ormond Street Institute of Child Health (Prof SE Mole PhD), UCL Institute of Ophthalmology (S-M kleine Holthaus PhD, A) Smith PhD), and UCL Schoo of Pharmacy (A A Rahim PhD), University College London, London, UK; Department of Histopathology, Great Ormond Street Hospital, London, UK (G Anderson FIBMS); Batten Disease Family Association, Farnborough, UK (H A Band MSc); Epilepsy Research Centre, Department of Medicine, Austin Health \& Northern Health, University of Melbourne, Melbourne, VIC, Australia (Prof S F Berkovic MD); Department of Pediatrics, Washington University School of Medicine, St Louis, MO, USA (Prof J D Cooper PhD) Centre for Bioscience, Manchester Metropolitan University, Manchester, UK (Prof T R McKay PhD); Telethon Institute of Genetics and Medicine, Naples, Italy (D L Medina PhD); and Department of Pediatrics, University Medical Center Hamburg-Eppendorf, Hamburg, Germany (A Schulz MD)

Correspondence to: Prof Sara E Mole, Medical Research Council Laboratory for Molecular Cell Biology, University College London, London, WC1E 6BT, UK s.mole@ucl.ac.uk 


\begin{tabular}{|c|c|c|c|c|c|c|c|}
\hline & Disease name(s) & Protein and location & $\begin{array}{l}\text { Number of } \\
\text { mutations }\end{array}$ & $\begin{array}{l}\text { Genotype-phenotype } \\
\text { correlation }\end{array}$ & Age of onset & $\begin{array}{l}\text { Typical clinical } \\
\text { feature } \neq\end{array}$ & $\begin{array}{l}\text { Ultrastructural } \\
\text { pathological features }\end{array}$ \\
\hline CLN1/PPT1* ${ }^{*}$ & $\begin{array}{l}\text { CLN1 disease, } \\
\text { Haltia-Santavuori disease }\end{array}$ & Lysosome enzyme & 71 & $\begin{array}{l}\text { Infantile } \neq \\
\text { Late infantile } \\
\text { Juvenile } \\
\text { Adult }\end{array}$ & $\begin{array}{l}6-12 \text { months } \\
1 \cdot 5-4 \text { years } \\
5-7 \text { years } \\
>16 \text { years }\end{array}$ & $\begin{array}{l}\text { Clumsiness, loss of } \\
\text { developmental } \\
\text { gains }\end{array}$ & $\begin{array}{l}\text { Granular osmiophilic } \\
\text { deposits }\end{array}$ \\
\hline CLN2/TPP1*† & $\begin{array}{l}\text { CLN2 disease, } \\
\text { Jansky-Bielschowsky disease }\end{array}$ & Lysosome enzyme & 121 & $\begin{array}{l}\text { Infantile } \\
\text { Late infantile } \ddagger \\
\text { Juvenile, protracted } \\
\text { Spinocerebellar ataxia } \dagger\end{array}$ & $\begin{array}{l}<18 \text { months } \\
2-4 \text { years } \\
>5 \text { years } \\
>11 \text { years }\end{array}$ & $\begin{array}{l}\text { Motor decline or } \\
\text { speech delay, } \\
\text { seizures }\end{array}$ & Curvilinear profiles \\
\hline $\mathrm{CLN}^{*}+$ & $\begin{array}{l}\text { CLN3 disease, } \\
\text { Spielmeyer-Vogt-Sjögren-Batten } \\
\text { disease }\end{array}$ & $\begin{array}{l}\text { Lysosomal } \\
\text { membrane protein }\end{array}$ & 78 & $\begin{array}{l}\text { Juvenile } \ddagger \\
\text { Protracted } \dagger \\
\text { Autophagic vacuolar } \\
\text { myopathy } \dagger \\
\text { Retinitis pigmentosa } \dagger \\
\text { Adult cone-rod dystrophy } \dagger\end{array}$ & $\begin{array}{l}\text { 4-7 years } \neq \\
>4 \text { years } \\
>7 \text { years } \\
>15 \text { years } \\
>20 \text { to }>40 \text { years }\end{array}$ & Visual failure & Fingerprint profiles \\
\hline $\begin{array}{l}\text { CLN4/ } \\
\text { DNAJC5* } 5^{*}\end{array}$ & CLN4 disease, Parry disease & $\begin{array}{l}\text { Cytoplasmic protein } \\
\text { that associates with } \\
\text { late endosome and } \\
\text { lysosome membrane }\end{array}$ & 2 & $\begin{array}{l}\text { Adult autosomal dominant } \\
\text { (Parry disease) }\end{array}$ & $>20$ years $\ddagger$ & $\begin{array}{l}\text { Seizures ataxia, } \\
\text { behavioural } \\
\text { changes }\end{array}$ & $\begin{array}{l}\text { Diverse and often } \\
\text { mixed }\end{array}$ \\
\hline CLN5 $5^{*}+$ & CLN5 disease & Lysosome enzyme & 37 & $\begin{array}{l}\text { Late infantile‡ } \\
\text { Juvenile } \\
\text { Adult }\end{array}$ & $\begin{array}{l}4-5 \text { years } \ddagger \\
5-7 \text { years } \\
>16 \text { to }>50 \text { years }\end{array}$ & $\begin{array}{l}\text { Slowing of } \\
\text { psychomotor } \\
\text { development, } \\
\text { visual failure }\end{array}$ & $\begin{array}{l}\text { Rectilinear profiles and } \\
\text { condensed storage } \\
\text { inclusions }\end{array}$ \\
\hline CLN6*† & $\begin{array}{l}\text { CLN6 disease, } \\
\text { Kufs disease type A }\end{array}$ & $\begin{array}{l}\text { Endoplasmic } \\
\text { reticulum membrane } \\
\text { protein }\end{array}$ & 70 & $\begin{array}{l}\text { Late infantile } \neq \\
\text { Progressive myoclonic } \\
\text { epilepsy } \\
\text { Teenage-adult Kufs type A } \\
\text { Juvenile cerebellar ataxia } †\end{array}$ & $\begin{array}{l}\geq 18 \text { months } \ddagger \\
>15 \text { years } \\
>15 \text { years } \\
>7 \text { years }\end{array}$ & $\begin{array}{l}\text { Seizures and motor } \\
\text { difficulties }\end{array}$ & $\begin{array}{l}\text { Rectilinear profiles and } \\
\text { condensed storage } \\
\text { inclusions }\end{array}$ \\
\hline $\begin{array}{l}\text { CLN7/ } \\
\text { MFSD8*+ }\end{array}$ & CLN7 disease & $\begin{array}{l}\text { Lysosomal } \\
\text { membrane protein }\end{array}$ & 38 & $\begin{array}{l}\text { Late infantile } \ddagger \\
\text { Juvenile, protracted } \\
\text { Adult macular dystrophy }{ }^{\dagger} \\
\text { Adult cone-rod dystrophy } \dagger\end{array}$ & $\begin{array}{l}1 \cdot 5-6 \text { years } \neq \\
>7 \text { years } \\
>29 \text { to }>65 \text { years } \\
>27 \text { years }\end{array}$ & $\begin{array}{l}\text { Seizures, } \\
\text { developmental } \\
\text { regression }\end{array}$ & $\begin{array}{l}\text { Rectilinear profiles and } \\
\text { condensed storage } \\
\text { inclusions }\end{array}$ \\
\hline CLN8*† & CLN8 disease & $\begin{array}{l}\text { Endoplasmic } \\
\text { reticulum membrane } \\
\text { protein }\end{array}$ & 35 & $\begin{array}{l}\text { Late infantile } \ddagger \\
\text { Protracted } \\
\text { EPMR/Northern epilepsy } \dagger\end{array}$ & $\begin{array}{l}2-7 \text { years } \ddagger \\
5-10 \text { years } \\
5-10 \text { years }\end{array}$ & Seizures & $\begin{array}{l}\text { Rectilinear profiles and } \\
\text { condensed storage } \\
\text { inclusions }\end{array}$ \\
\hline CLN10/CTSD* $\dagger$ & CLN10 disease, Congenital NCLs & Lysosome enzyme & 12 & $\begin{array}{l}\text { Congenital } \neq \\
\text { Late infantile } \\
\text { Juvenile } \\
\text { Adult }\end{array}$ & $\begin{array}{l}\text { Prenatal and perinatal } \neq \\
4 \text { years } \\
8-15 \text { years } \\
>20 \text { years }\end{array}$ & $\begin{array}{l}\text { Seizures, spasticity, } \\
\text { central sleep } \\
\text { apnoea }\end{array}$ & $\begin{array}{l}\text { Granular osmiophilic } \\
\text { deposits }\end{array}$ \\
\hline CLN11/GRN*† & CLN11 disease & $\begin{array}{l}\text { Lysosome enzyme } \\
\text { chaperone }\end{array}$ & $2 \S$ & $\begin{array}{l}\text { Adult } \neq \\
\text { Frontotemporal lobar } \\
\text { dementia (when } \\
\text { heterozygous) } \dagger\end{array}$ & $\begin{array}{l}>20 \text { years } \\
50-70 \text { years }\end{array}$ & $\begin{array}{l}\text { Rapidly progressive } \\
\text { visual failure, } \\
\text { seizures }\end{array}$ & Rectilinear profiles \\
\hline CLN13/CTSF* ${ }^{*}$ & $\begin{array}{l}\text { CLN13 disease, } \\
\text { Kufs disease type B }\end{array}$ & Lysosome enzyme & 11 & Adult Kufs type B $¥$ & $>20$ years & $\begin{array}{l}\text { Tremor, ataxia, } \\
\text { seizures }\end{array}$ & Fingerprint profiles \\
\hline
\end{tabular}

Note CLN9 is not identified. CLN=neuronal ceroid lipofuscinosis type; PPT1=palmitoyl protein thioesterase 1; TPP1= tripeptidyl peptidase 1; DNAJC5=Dna) homolog subfamily C member 5 (also known as cysteine string protein alpha or CSPa); MFSD8=major facilitator superfamily domain-containing protein 8; NCLs=neuronal ceroid lipofuscinoses; CTSD=cathepsin D; NCLs=neuronal ceroid lipofuscinoses; GRN=granulin; CTSF=cathepsin F; SCAR7= autosomal recessive spinocerebellar ataxia 7; EPMR=Epilepsy, Progressive, With Mental Retardation. *Variations in further genes have occasionally been linked with NCL-like phenotypes: CLN12/ATP13A2, mutations usually cause Kufor-Rakeb syndrome; CLN14/KCTD7 in cases with infantile and late infantile onset, all other known mutations cause a progressive myoclonic epilepsy or opsoclonus-myoclonus ataxia-like syndrome; SGSH in a case with adult onset, all other known mutations cause mucopolysaccharidosis type IIIA; CLCN6, perhaps modifying disease phenotype. ${ }^{3}+\mathrm{Non}-\mathrm{NCL}$ disease phenotype that could be more typically associated with other genes. $¥$ Phenotype caused by complete loss of gene function. \$Only the mutations that cause NCL when present on both disease alleles is enumerated; these mutation, and other mutations in this gene, cause later onset frontotemporal lobar dementia when present in heterozygous form. ${ }^{15}$

Table 1: Correlation between genotype and phenotype in neuronal ceroid lipofuscinoses

juvenile phenotype (age of onset 5-7 years) are usually visual loss, followed by dementia and behaviour changes, and then loss of motor skills and epilepsy in the early adolescence. ${ }^{1}$ In recessive adult phenotypes (more than 16 years of age) also referred to as Kufs disease, visual loss is usually absent, and patients present with progressive myoclonus epilepsy (type A) or dementia with motor decline (type B) typically around age 30 years, but symptom onset could range from 16 to 50 years of age. ${ }^{19}$

Even though all types of NCLs share a similar set of clinical features (eg, dementia, epilepsy, motor deterioration, and visual loss) their clinical severity and presentation often differs even for those caused by mutations in the same gene. Delay in expressive language 
development is the first sign of regression of psychomotor function in $83 \%$ of patients with classic late-infantile CLN2 disease and could enable early diagnosis. ${ }^{9}$ Children with a combination of language acquisition delay and new onset of seizures should be tested for CLN2 disease. ${ }^{9,20}$ Epilepsy is therapy-resistant in almost all patients with NCLs, with especially high seizure frequency and severity in lateinfantile CLN2 disease up until late stages of disease. ${ }^{20}$ However, in infantile neuronal ceroid lipofuscinosis type 1 (CLN1) disease, seizure frequency tends to decrease in the later stages of disease; in patients with classic juvenile CLN3 disease, seizures are infrequent with only mild worsening with later stages of disease. ${ }^{21,22}$ Therapy with more than two antiepileptic drugs could result in increased side-effects rather than a reduction of seizures. ${ }^{1}$ Some antiepileptic drugs are particularly recommended-valproate and lamotrigine for CLN2 and CLN3 diseases, ${ }^{21,22}$ however, others (eg, carbamazepine, gabapentin, phenytoin, or vigabatrin) might have negative effects-theyc ould exacerbate myoclonic seizures in patients with CLN2 or CLN3 disease. ${ }^{21-23}$ As disease progresses, anticonvulsive drugs that have been tolerated and effective might cause new side-effects, and should be reconsidered if symptoms of the disease worsen. ${ }^{22}$

Motor signs range from ataxia (including dysmetria and dysarthria) and dysphagia to myoclonus, chorea, tremor, and dystonia, especially in classic infantile and late-infantile phenotypes. ${ }^{1}$ Others include parkinsonism, especially in juvenile CLN3 disease, and some stereotypical movements have been reported in various types of NCLs with late-infantile and juvenile age of onset.

More NCL disease phenotypes are being recognised in which one of the clinical hallmarks might be more predominant and others absent. For example, in a rare type of CLN2 disease (autosomal recessive spinocerebellar ataxia type 7), ataxia is the primary phenotype with no accompanying epilepsy or vision loss, ${ }^{24}$ and in one type of juvenile CLN2 disease associated with a particular mutation, survival is into the fourth decade of life. ${ }^{25}$ Some patients with mutations in CLN3 have only isolated non-syndromic recessive retinal degeneration, ${ }^{26}$ and others experience visual failure, seizures, and cardiac involvement, but no motor deterioration even many decades after disease onset. $^{27}$ A pathophysiological link between NCLs and an adult degenerative dementia is assumed given that homozygous mutations in GRN cause NCLs presenting at around age 20 years with visual failure, seizures, and ataxia, whereas heterozygous mutations in this gene are a common cause of frontotemporal lobar degeneration with TDP-43 inclusions. ${ }^{3,15}$

\section{Neuroimaging and EEG findings}

Brain MRI scans can look normal in the early stages of the disease or might show some unspecific s igns, $\mathrm{s}$ uch a $\mathrm{s}$ periventricular intensity changes in early-stage CLN2 disease. $^{28}$ Although MRI is not sensitive or specific for early diagnosis, it is an excellent tool to objectively monitor the progression of brain changes, particularly with advances in resolution and processing, and neuroimaging techniques such as diffusion tensor imaging allow assessment of disorganisation of white matter tracts and atrophy. Two prospective studies ${ }^{28,29}$ in patients with CLN2 disease have shown that the loss of cortical grey matter volume with increasing age might be a sensitive biomarker to monitor disease progression.

EEG can be helpful in early diagnosis of some NCLs. For example, characteristic posterior spike waves were reported after low-frequency photic stimulation in $13(93 \%)$ of 14 patients with early stage of CLN2 disease. ${ }^{30}$ Finding posterior spike waves after photic stimulation in a child younger than 5 years with a new onset of seizures should trigger testing for CLN2 disease. ${ }^{30,31}$ Photosensitivity with low-frequency stimulation has also been reported in patients with neuronal ceroid lipofuscinosis type 6 (CLN6) disease, and especially in those with adult CLN6 disease (type A). ${ }^{32-34}$ In NCL forms that rapidly progress, such as infantile CLN1 disease, early abnormalities disappear as neurons die, leading to a characteristic flat EEG at advanced stages of disease. ${ }^{1}$ Because of the underlying neurometabolic disease, antiepileptic drugs will not lead to normalisation of the EEG findings, ${ }^{1}$ presumably because cells have died or are dying, and this in itself leads to seizures. Monitoring by EEG might be useful for detecting signs of encephalitis, which could be a rare consequence of antiepileptic drugs such as valproate in advanced late-infantile CLN2 disease, ${ }^{22}$ or theoretical allergic reaction to new treatments.

\section{Genotype-phenotype correlations}

The NCLs are monogenic disorders, so each is a separate disease entity. The genes associated with NCLs encode apparently unrelated proteins that include soluble lysosomal enzymes and membrane proteins localised in various organelles, including the lysosome (table 1). ${ }^{3,35,36}$ All types of NCLs are autosomal recessive with the exception of one rare adult onset NCL, neuronal ceroid lipofuscinosis type 4 (CLN4) disease. ${ }^{3}$ For most NCLs there is a recognisable classic disease phenotype associated with complete loss of gene function due to intracellular mislocalisation or degradation of the mutant protein. ${ }^{3}$ Later onset forms of disease that might have a more protracted overall course also occur and some anticipated classic phenotypes might be absent as a result of milder mutations that do not completely stop protein function (table 1). ${ }^{19}$ There are examples of mutations associated with a specific phenotype such as a missense mutation in CLN8 or the $1 \mathrm{~kb}$ intragenic deletion that underlies the most common form of NCLs, juvenile CLN3 disease. ${ }^{3}$ The most prevalent mutations are the $1 \mathrm{~kb}$ deletion in CLN3 and two mutations in CLN2. ${ }^{3}$ The combination of data collected in DEM-CHILD, ${ }^{9,10}$ NCL Mutation Database, and application of NCL disease rating scales ${ }^{11,12}$ allows correlations to be made between the disease and underlying mutations to provide some guidance to the expected disease course,
For more on DEM-CHILD see www.dem-child.eu For more on the NCL Mutation Database see www.ucl.ac.uk/nc 
and to give an approximation of frequency and occurrence in specific ethnic groups. As the phenotypic spectrum broadens, increasing overlap with other rare (eg, inborn errors of metabolism) and common diseases (eg, retinal dystrophies) that share similar disease mechanisms is expected, ${ }^{37}$ which could lead to better understanding of all these diseases.

\section{Diagnosis}

Diagnostic strategies vary according to the age of the patient, and can be guided by diagnostic algorithms. Enzyme testing can rapidly confirm some NCLs (table 1). The advent of new DNA technologies allows testing for many genes in a single step regardless of how typical the presentation is (eg, a panel can contain NCLs genes among a larger group of syndromic and non-syndromic inherited epilepsies). Blood film examination allows identification of vacuolated lymphocytes, which is a common feature of CLN3 disease. ${ }^{38}$ Ultrastructural examination of a skin biopsy or blood sample remains helpful for confirmation of NCL disease for atypical forms that are not enzyme deficiencies, or have not yet received a genetic diagnosis (table 1). Extracerebral storage is readily detected in childhood NCLs but not necessarily in NCLs presenting in adulthood. ${ }^{19}$ Prenatal diagnosis is available and can be offered to families with a history of NCL disease. Preimplantation genetic diagnosis ${ }^{39}$ or a combination of enzyme assay and mutational analysis, perhaps with ultrastructural examination of chorionic villus samples obtained at 12-15 weeks' gestation, can provide a rapid diagnosis.

\section{Pathology}

Neuronal loss is profound and widespread in most patients with NCLs resulting in cortical grey matter atrophy, cerebellar atrophy, and secondary ventricular enlargement. The degree of atrophy and ventricular enlargement varies between the NCL forms, but is typically preceded by clinical symptoms (eg, epilepsy). ${ }^{2,40}$ Nevertheless, this loss of neurons in the cerebral and cerebellar cortices is selective because cell loss is not spread evenly throughout the brain in childhood NCLs, and the thalamus can be severely affected..$^{2,40}$ In adult onset NCLs, brain atrophy is less obvious. ${ }^{2,40}$ Pronounced microglial and astrocytic activation precedes and perhaps causes neuron loss, ${ }^{19,41,42}$ accurately predicting its distribution. ${ }^{41}$ Brain atrophy of the cerebral cortex and enlargement of the subarachnoid space and ventricles progresses throughout the disease. ${ }^{2,40}$ Atrophy of the cerebellum is variable but evident in the later stages of all NCLs. ${ }^{28,29,43}$ Neuronal depletion in the retina commences in the photoreceptor outer segments, proceeding to the inner segments, nerve cell bodies, and ganglionic layer, and occurs early in CLN3 disease, ${ }^{4,45}$ while other symptoms (eg, epilepsy) precede visual loss in other types of NCLs. ${ }^{140}$ In all forms of NCLs lipopigment storage material accumulates in macrophages, neurons, and some somatic tissues, including vascular endothelial and smooth muscle cells. ${ }^{40}$ Lipopigments also accumulate in the CNS with increasing age, in healthy people, or neurological conditions such as mucopolysaccharidoses or GM1 gangliosidosis, ${ }^{40}$ and careful neuropathological assessment is needed to avoid misdiagnosis (eg, early-onset Alzheimer's disease). ${ }^{19}$

Mice that are genetically modified or have spontaneous mutations exist for all NCL genes, ${ }^{5,46}$ and their characterisation has provided insights into the staging of neuropathological changes. ${ }^{6,7}$ This has revealed differences in the extent, timing, and nature of changes ${ }^{41,42}$ despite leading to a similar pathological endpoint. The spinal cord has been identified as exhibiting important pathology, including loss of neurons, activation of microglia, and build-up of lipopigment storage in $C \ln 1$ mice, ${ }^{47}$ with impairments of the peripheral nervous system evident resembling paroxysmal sympathetic hyperactivity in juvenile CLN3 disease. ${ }^{48}$ Pathological changes have also been described in somatic tissues, including heart (eg, repolarisation disturbances, ventricular hypertrophy, sinus node dysfunction), ${ }^{17}$ and establishing its relationship to events in the CNS will be important. Knowing where and when pathology occurs is crucial for the effective targeting of experimental therapies. In this respect, studies with animals that have larger brains (eg, sheep and dogs) will be required. ${ }^{5,8}$ In addition to their larger and more complex brains for scaling up the delivery of therapies, the extent of pathology and its regionalised nature is more pronounced in the brains of sheep and dogs with NCLs than in corresponding mouse models (possibly because of the size difference), and pathology appears to more closely resemble that of human cases. ${ }^{6,7}$ With the ability to engineer genetically modified pigs and sheep, such species might prove invaluable for further understanding the effects of the disease and to improve therapies.

\section{Technical advances}

The development of induced pluripotent stem cell (iPSC) technology has been crucial for understanding and treating genetic diseases using cell models. Cells obtained from a skin or blood sample can be genetically reprogrammed to a state of pluripotency and are capable of differentiating into virtually any cell type, including neuronal subtypes. ${ }^{49}$ Neural cells differentiated from patient-derived iPSC display autophagic, lysosomal maturation, and mitochondrial quality control defects for CLN3 disease and tripeptidyl peptidase 1 (TPP1) enzyme deficiency for CLN2 disease. ${ }^{50}$ In 2017, two repositories of NCLs iPSC lines became available to academic researchers. The Human Pluripotent Stem Cell Initiative in the UK, released 12 lines from patients with CLN1 CLN3, CLN6, CLN7, CLN8, and CLN10 mutations, and in the USA the Beyond Batten Disease Foundation, in alliance with the New York Stem Cell Foundation, publicised a resource of iPSC generated from 24 individuals from CLN3 disease families. However, such patient-derived cells are genetically diverse. The use of 
clustered regularly spaced short palindromic repeats (CRISPR)-Cas9 gene editing technology to introduce specific genetic changes into a parental pluripotent line allows the production of isogenic lines representing selected mutations of NCL genes that can more readily be compared. ${ }^{51}$ Such repositories, along with further individually generated iPSC lines ${ }^{52}$ and engineered stem cells, represent the next generation of cellular tools to better understand the causes of NCLs. Patient iPSCderived neural cells have already been used as a therapeutic evaluation platform for NCLs, including high-throughput screening (appendix).

\section{Emerging therapies}

There have been extensive studies using animal models in developing new treatments for NCLs (appendix). The main translational approaches are summarised, beginning with the most advanced and promising approaches.

\section{Enzyme replacement therapy}

Intracerebroventricularly administered enzyme replacement therapy in CLN2 disease is the first t reatment approved by the FDA and EMA, and treatment is expected to be needed throughout the patient's life. , $^{1053}$ The deficient enzyme TPP1 is administered over $4 \mathrm{~h}$ as a recombinant proenzyme via a Rickham or Ommaya reservoir into the lateral cerebral ventricles at a dose of $300 \mathrm{mg}$ of protein every 2 weeks into the brain of children with CLN2 disease. ${ }^{10}$ Safety and efficacy were tested in an openlabel, dose-escalation study lasting up to 12 weeks ${ }^{10}$ that enrolled 24 patients aged 3-16 years with CLN2 disease, followed by a 48 week period in which they received a stable dose of the protein and then had the option to enroll into a 240 week extension study. Most patients (21 [92\%]) had lost some language or motor skills according to the CLN2 Clinical Rating Scale by the trial's start. Of the 23 (96\%) patients who completed the study, ${ }^{10} 18$ (78\%) had either a slower than expected disease progression or stabilisation of the disease measured by rating the motor and language function of patients after at least 96 weeks of treatment (median 116 weeks, range 96-145) at the $300 \mathrm{mg}$ dose.$^{10}$ Notably, two of those patients who had the highest initial baseline scores maintained these for the duration of the study, indicating that starting treatment early is likely to be most beneficial. A ntibodies $d$ eveloped a gainst the drug but were not linked to safety concerns or a poor treatment outcome. ${ }^{54}$ The 23 patients continue to be treated and followed up to evaluate the long-term efficacy an d sa fety (N CT02485899). A se cond st udy (NCT02678689) has begun to monitor the effects of beginning treatment earlier in the disease course in a separate group of patients (table 2). The cross-corrective approach of enzyme replacement therapy depends on delivered enzyme being recognised by receptors on the surface of cells, taken into the cell and trafficked to the lysosome, and the same enzyme replacement approach might be suitable for other types of NCLs caused by mutations in lysosomal enzymes (CLN1/palmitoyl protein thioesterase [PPT1], CLN2/TPP1, neuronal ceroid lipofuscinosis type 5 [CLN5], CLN10/CTSD, and neuronal ceroid lipofuscinosis type 13 [CLN13]/cathepsin F [CTSF]); (table 1). The therapy could be delivered frequently and periodically as a recombinant product, or alternatively could be produced and released continually within the body following gene therapy or cell-based therapy.

\section{Gene therapy}

Gene therapy studies using viral vectors to introduce a healthy NCL gene into animal models for NCLs have mainly focused on targeting the brain for diseases caused by lysosomal enzyme deficiencies, which should be less challenging to treat than those caused by mutations in integral transmembrane-bound proteins because of advantages provided by cross-correction. ${ }^{59}$ Clinical studies and animal models suggest that gene therapy approaches targeting only the brain ${ }^{10,60}$ are unlikely to provide therapeutic benefit for the NCL-related retinal degeneration. A combinatorial gene therapy approach that separately treats the brain and the eye is likely to be required for optimal therapy. ${ }^{61}$

The first gene therapy phase 1 clinical trial ${ }^{62}$ was done in ten patients with CLN2 disease aged 3-10 years to test the safety of introducing a gene therapy vector designed to express TPP1 into the brain. The vector was safe but there was no slowing of disease progression. Given the experience with enzyme replacement therapy, ${ }^{10}$ a vector and delivery that results in TPP1 reaching more cells is likely to be required to achieve better therapeutic outcome. Orphan drug designation has been granted for adeno-associated virus-mediated gene therapy for CLN1 and CLN3 diseases, and clinical trials are anticipated. A phase 1/2 trial (NCT02725580) in patients with CLN6 disease to assess intrathecal administration of AAV9mediated gene therapy is ongoing (table 2). The preceding animal studies in which efficacy of these vectors was tested are not yet published, making evaluation of the likelihood of clinical benefit difficult. .3,64 $^{-6}$

\section{Pharmacological approaches}

As for most lysosomal storage disorders, many of the pharmacological treatments for NCLs are palliative, focused on minimising clinical symptoms such as seizures, and do not target the underlying cause of the disease. ${ }^{1}$ Animal models and clinical observations have provided a variety of potential targets to modulate disease (eg, antiinflammatories, molecular chaperones, enzyme mimics, Bcl-2 upregulators, NMDA and AMPA receptor antagonists, calcium-channel blockers, immunosuppressants, and antioxidants). ${ }^{55,65-69}$ However, follow-up studies using these compounds have not shown clinically meaningful benefits for patients, ${ }^{57,58}$ including targeting neuroinflammation in the eye for CLN3 disease. $^{70}$ Some parents giving the drug flupirtine to their children with juvenile CLN3 disease have anecdotally reported benefit; however, quantitative,
See Online for appendix 


\begin{tabular}{|c|c|c|c|c|c|c|}
\hline & Study title and NCT number & Treatment & Phase and status & $\mathbf{N}$ & Location & Outcome \\
\hline CLN1 & $\begin{array}{l}\text { Cystagon to treat infantile neuronal ceroid lipofuscinosis } \\
\text { (a combination therapy with cystagon and } \\
\text { N-acetylcysteine for INCL patients), NCT00028262 }\end{array}$ & Mercaptamine & 4, published & 9 & USA & Little or no clinical benefit ${ }^{55}$ \\
\hline CLN1 and CLN2 & $\begin{array}{l}\text { Study of human central nervous system stem cells } \\
\text { (HuCNS-SC) cells in patients with infantile or late } \\
\text { infantile neuronal ceroid lipofuscinosis, NCT00337636 }\end{array}$ & Stem cells & 1, published & 6 & USA & Little or no clinical benefit ${ }^{56}$ \\
\hline CLN1 & $\begin{array}{l}\text { Safety and efficacy study of human central nervous } \\
\text { system stem cells in subjects with neuronal ceroid } \\
\text { lipofuscinosis, NCT01238315 }\end{array}$ & Stem cells & $\begin{array}{l}\text { 1, withdrawn prior } \\
\text { to enrolment }\end{array}$ & 0 & USA & .. \\
\hline CLN2 & $\begin{array}{l}\text { Safety study of a gene transfer vector for children with } \\
\text { late infantile neuronal ceroid lipofuscinosis, } \\
\text { NCT00151216 }\end{array}$ & AAV2CUhCLN2 gene transfer & $1_{n}$, published & 10 & USA & Little or no clinical benefit ${ }^{57}$ \\
\hline CLN2 & $\begin{array}{l}\text { Safety study of a gene transfer vector (rh.10) for children } \\
\text { with late infantile neuronal ceroid lipofuscinosis, } \\
\text { NCT01161576 }\end{array}$ & $\begin{array}{l}\text { AAVrh.10CUhCLN2 gene } \\
\text { transfer }\end{array}$ & 1 , ongoing & 25 & USA & .. \\
\hline CLN2 & $\begin{array}{l}\text { AAVrh.10 administered to children with late infantile } \\
\text { neuronal ceroid lipofuscinosis with uncommon } \\
\text { genotypes or moderate/severe impairment, } \\
\text { NCT01414985 }\end{array}$ & $\begin{array}{l}\text { AAVrh.10CUhCLN2 gene } \\
\text { transfer }\end{array}$ & $1 / 2$, ongoing & 8 & USA & .. \\
\hline CLN2 & $\begin{array}{l}\text { A phase } 1 / 2 \text { open-label dose-escalation study to evaluate } \\
\text { safety, tolerability, pharmacokinetics, and efficacy of } \\
\text { intracerebroventricular BMN } 190 \text { in patients with late- } \\
\text { infantile neuronal ceroid lipofuscinosis (CLN2) disease, } \\
\text { NCT01907087 }\end{array}$ & $\begin{array}{l}\text { rhTPP1 BMN190 } \\
\text { (Cerliponase alfa) } \\
\text { (recombinant human } \\
\text { tripeptidyl peptidase-1) }\end{array}$ & 1/2, published & 24 & $\begin{array}{l}\text { Germany, UK, Italy, } \\
\text { USA }\end{array}$ & $\begin{array}{l}\text { Clinical improvement or } \\
\text { stabilization }{ }^{28} \\
\text { FDA and EMA approval }\end{array}$ \\
\hline CLN2 & $\begin{array}{l}\text { A multicenter, multinational, extension study to evaluate } \\
\text { the long-term efficacy and safety of BMN } 190 \text { in patients } \\
\text { with CLN2 disease, NCT02485899 }\end{array}$ & $\begin{array}{l}\text { rhTPP1 BMN190 } \\
\text { (Cerliponase alfa) } \\
\text { (recombinant human } \\
\text { tripeptidyl peptidase-1) }\end{array}$ & $1 / 2$, ongoing & 23 & $\begin{array}{l}\text { Germany, UK, Italy, } \\
\text { USA }\end{array}$ & .. \\
\hline CLN2 & $\begin{array}{l}\text { A safety, tolerability, and efficacy study of } \\
\text { intracerebroventricular BMN } 190 \text { in patients with CLN2 } \\
\text { disease, NCT02678689 }\end{array}$ & $\begin{array}{l}\text { rhTPP1 BMN190 } \\
\text { (Cerliponase alfa) } \\
\text { (recombinant human } \\
\text { tripeptidyl peptidase-1) }\end{array}$ & 2 , ongoing & 15 & Germany, Italy, USA & .. \\
\hline CLN3 & $\begin{array}{l}\text { Cellcept for treatment of juvenile neuronal ceroid } \\
\text { lipofuscinosis, NCT01399047 }\end{array}$ & Mycophenolate mofetil & 2, published & 19 & USA & Little or no clinical benefit ${ }^{58}$ \\
\hline CLN6 & $\begin{array}{l}\text { Phase I/Ila gene transfer clinical trial for variant late } \\
\text { infantile neuronal ceroid lipofuscinosis, delivering the } \\
\text { CLN6 gene by self-complementary AAV9, NCT02725580 }\end{array}$ & $\begin{array}{l}\text { scAAV9.CB.CLN6 gene } \\
\text { transfer }\end{array}$ & $1 / 2$, ongoing & 12 & USA & .. \\
\hline $\begin{array}{l}\text { NCL \& other } \\
\text { diseases }\end{array}$ & $\begin{array}{l}\text { UCB transplant of inherited metabolic diseases with } \\
\text { administration of intrathecal UCB derived } \\
\text { oligodendrocyte-like cells (DUOC-01), NCT02254863 }\end{array}$ & $\begin{array}{l}\text { Adjunct therapy for UCB- } \\
\text { derived oligodendrocyte-like } \\
\text { cells (DUOC-01) to HSCT }\end{array}$ & 1 , ongoing & 12 & USA & \\
\hline $\begin{array}{l}\text { NCL \& other } \\
\text { diseases }\end{array}$ & $\begin{array}{l}\text { Human placental-derived stem cell transplantation, } \\
\text { NCT01586455 }\end{array}$ & $\begin{array}{l}\text { Stem cells (administered in } \\
\text { conjunction with umbilical } \\
\text { cord blood stem cells) }\end{array}$ & 1 , ongoing & 43 & USA & \\
\hline
\end{tabular}

prospectively obtained data did not show any change in disease progression that could be attributed to this drug. ${ }^{71}$ A clinical trial treating 19 children with juvenile CLN3 disease with a non-steroidal immunosuppressive drug, mycophenolate mofetil, over two 8-week treatment periods with a 4-week intervening washout ${ }^{68,69}$ showed that this drug was well tolerated, but there was no clinical benefit. ${ }^{58}$ A trial in nine children with CLN1 disease that tested the combination of phosphocysteamine and N-acetylcysteine, reported no clinical benefit (table 2). ${ }^{57}$ Thus, to date no efficacy is supported for any of these pharmacological treatments. Rather than targeting secondary downstream effects (eg, build up of storage material) focus should be directed to understanding the underlying disease mechanisms.

Applying a classic drug discovery approach (from disease mechanism to target to drug) to the NCLs is challenging because little is known about which intracellular pathways are affected or if they are good candidates for drug therapy. In addition, drugs need to cross the blood-brain barrier to reach the brain. Molecular pathways common to neurodegenerative diseases (neuroinflammation, impairment of autophagy, defects in endocytic trafficking, mitochondrial alterations, or impairment in calcium homoeostasis) $)^{2,73}$ might be promising targets and could be entry points to cell-based phenotypic screening approaches. For example, 
a screen of bioactive compounds using cells from the $\mathrm{Cln} 3$ mouse model that had elevated levels of a marker protein for autophagy identified modulators of autophagy that included some known to target ion channels and especially calcium channels and proteolysis inhibitors. ${ }^{74,75}$ Discovery of transcriptional regulation of lysosomal biogenesis and degradative function by the transcription factor EB has opened a new avenue for therapeutic intervention in lysosomal storage disorders. ${ }^{76-79}$ For example, stimulation of transcription factor EB with trehalose affords benefits in $\mathrm{Cln}^{78}$ and mucopolysaccharidosis type III ${ }^{80}$ disease mice. The FDA-approved lipid-lowering drug gemfibrozil a lso a ctivates the $s$ ame $p$ athway ${ }^{81,82}$ a nd $h$ as moderate beneficial effects in $C \ln 2$ mice. ${ }^{83,84} \mathrm{~A}$ clinical trial to test efficacy of these approaches is yet to be launched in patients with any form of NCLs. Drug approaches for NCLs could compensate for missing functional activities and slow or prevent cell death and these treatments will probably be used to supplement other treatments and methods such as gene therapy.

\section{Cell-based therapy}

Although the original hope of cell-based therapy lies in its theoretical ability to replace cells lost in advanced disease, the degree of replacement required for lost CNS neurons would need to be substantial. However, this seems unlikely to happen because the therapy is not capable of replacing enough cells in the brain of a mouse (which is smaller than a human brain and its regions are easier to reach) which makes it unlikely that sufficient cell re population will happen in a human brain. ${ }^{63}$ The aim of stem cell trials for the NCLs is to preserve remaining function by providing cells that secrete a missing lysosomal enzyme. ${ }^{64}$ These cell factories will either need to be located where the enzyme is needed (eg, in the brain or eye) or the secreted enzyme will need to be transported in the blood and taken up by distant tissues (eg, heart), and will need to cross the blood-brain barrier to reach the brain. Ideally, such cells would be derived from an individual patient, manipulated to produce the required product by an introduced vector or by correcting the cell's own genome, and then being reintroduced. A phase 1 trial established the safety of neuroprogenitor cell implantation in six patients with advanced CLN1 or CLN2 disease (table 2). ${ }^{56}$ There was no clinical benefit t ot his t rial, $\mathrm{p}$ erhaps $\mathrm{b}$ ecause $\mathrm{d}$ onor engraftment was low and migration limited. ${ }^{56}$ There is an ongoing phase 1 trial (NCT01586455) testing whether transplantation of human placental-derived stem cells benefits patients with a range of diseases including NCLs (table 2).

\section{Conclusions and future directions}

The genetic basis of the NCLs is now well understood with the underlying genes encoding mainly lysosomal enzymes or membrane proteins. Correlation of genotype with clinical phenotype has broadened recognition of an NCL disorder, and at the same time provided the gene-based
Search strategy and selection criteria

We searched PubMed for articles only written in the English language and published between Jan 1, 2012, and Sept 30, 2018, using the search terms "ceroid", "Batten", "NCL", "CLN", "PPT1", "TPP1", "DNAJC5", "MFSD8", "CTSD", "GRN", “CTSF", "CLN1", "CLN2", “CLN3", “CLN4", “CLN5", "CLN6", "CLN7", "CLN8", "CLN10", "CLN11", "CLN12", and "CLN13". The final reference list was generated on the basis of relevance to the topics covered in this Review.

focus and consideration of pathological targets required for therapeutic advances. This knowledge has prompted therapeutic development beyond current palliative treatments, even without understanding disease mechanisms. Strategies for treatment of NCLs caused by defects in lysosomal enzymes benefit from the process of crosscorrection, leading to the first approved treatment for CLN2 disease that delivers recombinant protein directly into the brain at regular intervals. Development of a gene supplement approach is at the experimental stage for many NCLs, with the first of an anticipated new wave of clinical trials focusing on CLN6 disease. The results of clinical trials using pharmacological treatments are less convincing, perhaps because primary disease targets or pathways remain to be elucidated. Cell-based therapies have the potential to deliver lysosomal enzymes continually, and might be especially useful for treatment beyond the CNS, but they are in the early stages of development.

To have a long-term clinical benefit, treatment for the NCLs must begin early, ideally before any symptoms. This will require rapid and earlier diagnosis, which is aided by advances in DNA-based approaches, and highlights the importance of developing appropriate newborn screening. ${ }^{85,86}$ It will also be important to consider patients with milder and adult onset NCL forms who might particularly benefit from new treatments because there is a longer time window to diagnose patients before symptoms advance too far and are irreversible. ${ }^{19}$ International cooperation is contributing to the ongoing collection of natural history data for all NCL types into the DEM-CHILD database which can provide necessary control data for use in future clinical trials and increase understanding of the spectrum of each genetic type. ${ }^{10}$ A natural history database helps to solve the ethical dilemma of treating a proportion of trial patients with placebo because these patients' symptoms would advance so quickly that there would be no hope of recovery once actual treatment starts, and speeds up the development of therapy options in rare diseases for which availability of suitable patients for a trial can be a limiting factor.

Treatment for NCLs must reach the most affected cells in the brain and eye, and further studies are needed to fully understand the burden of disease outside the CNS and the need to target the periphery. Fortunately, new vectors are emerging for gene supplementation therapies that 
increase the ability to deliver treatments to cells within the brain or eye. ${ }^{87}$ This needs to be balanced against toxicity arising from producing too much recombinant protein within sensitive cells. ${ }^{88}$ An ideal least-invasive therapy would be a set of one-off or infrequent gene therapies that together target the whole body and are supplemented by probably lifelong drug-based modulation. Understanding of the molecular basis of the NCLs and the means to assess the effectiveness of any new treatment at a molecular level should be a future priority. This step is required for a breakthrough in pharmacological treatments that target pathways close to the underlying defect. Such advances will be beneficial for basic research, early diagnosis, and disease prevention.

\section{Contributors}

SEM devised the structure of the article; performed the search strategy; made the final selection of references; contributed to writing of the summary, introduction, the genetic basis and genotype-phenotype correlations, and tables; and provided oversight, harmonisation, and final editing of all sections. SFB and AS contributed to writing of the clinical features. GA contributed to writing of the diagnosis and pathology. DLM contributed to writing of the pharmacological approaches. TRM contributed to writing of the technical advances and iPSC cells and cell-based therapy. S-MKH, AJS, and AAR contributed to writing of the gene therapy. AS contributed to writing of the enzyme replacement therapy. JDC contributed to writing of the pathology and disease mechanisms and mouse models. SEM and HAB contributed to the writing of the conclusions and future directions.

\section{Declaration of interests}

SEM has received grants from the EU Horizon 2020 research and innovation programme under grant agreement No. 666918 (BATCure), the Batten Disease Family Association, and Biomarin; has received personal fees from Biomarin; receives salary support from University College London (UCL); and Medical Research Council (MRC) provides funding to the MRC Laboratory for Molecular Cell Biology University Unit at UCL (award code MC_U12266B) towards lab and office space. SFB has received grants from UCB Pharma, Eisai, and SciGen; has a patent (8288096) for SCN1A testing held by Bionomics Inc and licensed to various diagnostic companies, with no financial return; and was a consultant to Bionomics and Athena diagnostics before 2014. JDC has received research support from BioMarin Pharmaceuticals Inc, Abeona Therapeutics Inc, and Cerespir Inc; and also acts as a consultant for Regenexbio Inc. All other authors declare no competing interest.

\section{Acknowledgments}

We thank clinicians, scientists, and families who participate in the NCL Disease Registry and NCL Mutation Database, allowing more comprehensive understanding of this disease.

\section{References}

1 Schulz A, Kohlschutter A, Mink J, Simonati A, Williams R. NCL diseases-clinical perspectives. Biochim Biophys Acta 2013; 1832: 1801-06.

2 Radke J, Stenzel W, Goebel HH. Human NCL neuropathology. Biochim Biophys Acta 2015; 1852: 2262-66.

3 Mole SE, Cotman SL. Genetics of the neuronal ceroid lipofuscinoses (Batten disease). Biochim Biophys Acta 2015; 1852: 2237-41.

4 Williams RE, Mole SE. New nomenclature and classification scheme for the neuronal ceroid lipofuscinoses. Neurology 2012; 79: 183-91.

5 Faller KM, Gutierrez-Quintana R, Mohammed A, et al. The neuronal ceroid lipofuscinoses: opportunities from model systems. Biochim Biophys Acta 2015; 1852: 2267-78.

6 Palmer DN, Barry LA, Tyynela J, Cooper JD. NCL disease mechanisms. Biochim Biophys Acta 2013; 1832: 1882-93.

7 Cooper JD, Tarczyluk MA, Nelvagal HR. Towards a new understanding of NCL pathogenesis. Biochim Biophys Acta 2015; 1852: 2256-61
8 Weber K, Pearce DA. Large animal models for Batten disease: a review. J Child Neurol 2013; 28: 1123-27.

9 Nickel M, Simonati A, Jacoby D, et al. Disease characteristics and progression in patients with late-infantile neuronal ceroid lipofuscinosis type 2 (CLN2) disease: an observational cohort study. Lancet Child Adolesc Health 2018; 2: 582-90.

10 Schulz A, Ajayi T, Specchio N, et al. Study of intraventricular cerliponase alfa for CLN2 disease. N Engl J Med 2018; 378: 1898-907.

11 Steinfeld R, Heim P, Von Gregory H, et al. Late infantile neuronal ceroid lipofuscinosis: quantitative description of the clinical course in patients with CLN2 mutations. Am J Med Genet 2002; 112: 347-54

12 Kwon JM, Adams H, Rothberg PG, et al. Quantifying physical decline in juvenile neuronal ceroid lipofuscinosis (Batten disease). Neurology 2011; 77: 1801-07.

13 US Food and Drug Administration. FDA approves first treatment for a form of Batten disease. April 27, 2017. https://www.fda.gov/ NewsEvents/Newsroom/PressAnnouncements/ucm555613.htm (accessed Nov 8, 2018).

14 European Medicines Agency. European public assessment report. May 2017. https://www.ema.europa.eu/medicines/human/EPAR/ brineura (accessed Nov 8, 2018).

15 Smith KR, Damiano J, Franceschetti S, et al. Strikingly different clinicopathological phenotypes determined by progranulin-mutation dosage. Am J Hum Genet 2012; 90: 1102-07.

16 Lebrun AH, Moll-Khosrawi P, Pohl S, et al. Analysis of potential biomarkers and modifier genes affecting the clinical course of CLN 3 disease. Mol Med 2011; 17: 1253-61.

17 Ostergaard JR, Rasmussen TB, Molgaard H. Cardiac involvement in juvenile neuronal ceroid lipofuscinosis (Batten disease). Neurology 2011; 76: 1245-51.

18 Dilaveris P, Koutagiar I, Aggeli C, Sideris S, Gatzoulis K, Stefanadis C. Severe sinus node dysfunction in a patient with juvenile neuronal ceroid lipofuscinosis. Int J Cardiol 2014; 174: 143-46.

19 Berkovic SF, Staropoli JF, Carpenter S, et al. Diagnosis and misdiagnosis of adult neuronal ceroid lipofuscinosis (Kufs disease). Neurology 2016; 87: 579-84.

20 Williams RE, Adams HR, Blohm M, et al. Management strategies for CLN2 Disease. Pediatr Neurol 2017; 69: 102-12.

21 Augustine EF, Adams HR, Beck CA, et al. Standardized assessment of seizures in patients with juvenile neuronal ceroid lipofuscinosis. Dev Med Child Neurol 2015; 57: 366-71.

22 Johannsen J, Nickel M, Schulz A, Denecke J. Considering valproate as a risk factor for rapid exacerbation of complex movement disorder in progressed stages of late-infantile cln2 disease. Neuroped 2016; 47: $194-96$.

23 Mole SE, Williams RE, Goebel HH. The neuronal ceroid lipofusinoses (Batten disease), 2nd edn. Oxford: Oxford University Press, 2011.

24 Sun Y, Almomani R, Breedveld GJ, et al. Autosomal recessive spinocerebellar ataxia 7 (SCAR7) is caused by variants in TPP1, the gene involved in classic late-infantile neuronal ceroid lipofuscinosis 2 disease (CLN2 disease). Hum Mutat 2013; 34: 706-13.

25 Kohan R, Carabelos MN, Xin W, et al. Neuronal ceroid lipofuscinosis type CLN2: a new rationale for the construction of phenotypic subgroups based on a survey of 25 cases in South America. Gene 2013; 516: 114-21.

$26 \mathrm{Ku}$ CA, Hull S, Arno G, et al. Detailed clinical phenotype and molecular genetic findings in CLN3-associated isolated retinal degeneration. JAMA ophthalmology 2017; 135: 749-60.

27 Cortese A, Tucci A, Piccolo G, et al. Novel CLN3 mutation causing autophagic vacuolar myopathy. Neurology 2014; 82: 2072-76.

28 Dyke JP, Sondhi D, Voss HU, et al. Brain region-specific degeneration with disease progression in late infantile neurona ceroid lipofuscinosis (CLN2 disease). Am J Neuroradiol 2016; 37: $1160-69$.

29 Lobel U, Sedlacik J, Nickel M, et al. Volumetric description of brain atrophy in neuronal ceroid lipofuscinosis 2: supratentorial gray matter shows uniform disease progression. Am J Neuroradiol 2016; 37: 1938-43.

30 Specchio N, Bellusci M, Pietrafusa N, Trivisano M, de Palma L, Vigevano F. Photosensitivity is an early marker of neuronal ceroid lipofuscinosis type 2 disease. Epilepsia 2017; 58: 1380-88. 
31 Albert DV, Yin H, De Los Reyes EC, Vidaurre J. Unique characteristics of the photoparoxysmal response in patients with neuronal ceroid lipofuscinosis type 2: can EEG be a biomarker? J Child Neurol 2016; 31: 1475-82.

32 Canafoglia L, Gilioli I, Invernizzi F, et al. Electroclinical spectrum of the neuronal ceroid lipofuscinoses associated with CLN6 mutations. Neurology 2015; 85: 316-24.

33 Ozkara C, Gunduz A, Coskun T, et al. Long-term follow-up of two siblings with adult-onset neuronal ceroid lipofuscinosis, Kufs type A. Epileptic Disord 2017; 19: 147-51.

34 Lv Y, Zhang N, Liu C, Shi M, Sun L. Occipital epilepsy versus progressive myoclonic epilepsy in a patient with continuous occipital spikes and photosensitivity in electroencephalogram: a case report. Medicine (Baltimore) 2018; 97: e0299.

35 Huber RJ, Mathavarajah S. Cln5 is secreted and functions as a glycoside hydrolase in Dictyostelium. Cell Signal 2018; 42: 236-48.

36 Cárcel-Trullols J, Kovács AD, Pearce DA. Cell biology of the NCL proteins: what they do and don't do. Biochim Biophys Acta 2015; 1852: 2242-55.

37 Cotman SL, Mole SE, Kohan R. Future perspectives: Moving towards NCL treatments. Biochim Biophys Acta 2015; 1852: 2336-38.

38 Anderson G, Smith VV, Malone M, Sebire NJ. Blood film examination for vacuolated lymphocytes in the diagnosis of metabolic disorders; retrospective experience of more than 2500 cases from a single centre. J Clin Pathol 2005; 58: 1305-10.

39 Shen J, Cram DS, Wu W, et al. Successful PGD for late infantile neuronal ceroid lipofuscinosis achieved by combined chromosome and TPP1 gene analysis. Reprod Biomed Online 2013; 27: 176-83.

40 Anderson GW, Goebel HH, Simonati A. Human pathology in NCL. Biochim Biophys Acta 2013; 1832: 1807-26.

41 Parviainen L, Dihanich S, Anderson GW, et al. Glial cells are functionally impaired in juvenile neuronal ceroid lipofuscinosis and detrimental to neurons. Acta Neuropathol Commun 2017; 5: 74.

42 Lange J, Haslett LJ, Lloyd-Evans E, et al. Compromised astrocyte function and survival negatively impact neurons in infantile neuronal ceroid lipofuscinosis. Acta Neuropathol Commun 2018; 6: 74.

43 Baker EH, Levin SW, Zhang Z, Mukherjee AB. MRI brain volume measurements in infantile neuronal ceroid lipofuscinosis. Am J Neuroradiol 2017; 38: 376-82.

44 Preising MN, Abura M, Jager M, Wassill KH, Lorenz B. Ocular morphology and function in juvenile neuronal ceroid lipofuscinosis (CLN3) in the first decade of life. Ophthalmic Genet 2016; 38: 252-59.

45 Dulz S, Wagenfeld L, Nickel M, et al. Novel morphological macular findings in juvenile CLN3 disease. Br J Ophthalmol 2016; 100: $824-28$.

46 Bond M, Holthaus SM, Tammen I, Tear G, Russell C. Use of model organisms for the study of neuronal ceroid lipofuscinosis. Biochim Biophys Acta 2013; 1832: 1842-65.

47 Shyng C, Nelvagal HR, Dearborn JT, et al. Synergistic effects of treating the spinal cord and brain in CLN1 disease. Proc Natl Acad Sci USA 2017; 114: e5920-29.

48 Ostergaard JR. Paroxysmal sympathetic hyperactivity in Juvenile neuronal ceroid lipofuscinosis (Batten disease). Auton Neurosci 2018; 214: $15-18$.

49 Khurana V, Tardiff DF, Chung CY, Lindquist S. Toward stem cell-based phenotypic screens for neurodegenerative diseases. Nat Rev Neurol 2015; 11: 339-50.

50 Lojewski X, Staropoli JF, Biswas-Legrand S, et al. Human iPSC models of neuronal ceroid lipofuscinosis capture distinct effects of TPP1 and CLN3 mutations on the endocytic pathway. Hum Mol Genet 2014; 23: 2005-22.

51 Chaterji S, Ahn EH, Kim DH. CRISPR Genome engineering for human pluripotent stem cell research. Theranostics 2017; 7: 4445-69.

52 Uusi-Rauva K, Blom T, von Schantz-Fant C, Blom T, Jalanko A, Kyttala A. Induced pluripotent stem cells derived from a CLN5 patient manifest phenotypic characteristics of neuronal ceroid lipofuscinoses. Int J Mol Sci 2017; 18: e955.

53 Markham A. Cerliponase alfa: first global approval. Drugs 2017; 77: 1247-49.

54 Cherukuri A, Cahan H, de Hart G, et al. Immunogenicity to cerliponase alfa intracerebroventricular enzyme replacement therapy for CLN2 disease: results from a phase 1/2 study. Clin Immunol 2018; 197: 68-76.
55 Saha A, Sarkar C, Singh SP, et al. The blood-brain barrier is disrupted in a mouse model of infantile neuronal ceroid lipofuscinosis: amelioration by resveratrol. Hum Mol Genet 2012; 21: 2233-44.

56 Selden NR, Al-Uzri A, Huhn SL, et al. Central nervous system stem cell transplantation for children with neuronal ceroid lipofuscinosis. J Neurosurg Pediatr 2013; 11: 643-52.

57 Levin SW, Baker EH, Zein WM, et al. Oral cysteamine bitartrate and $\mathrm{N}$-acetylcysteine for patients with infantile neuronal ceroid lipofuscinosis: a pilot study. Lancet Neurol 2014; 13: 777-87.

58 Augustine EF, Beck CA, Adams HR, et al. Short-term administration of mycophenolate is well- tolerated in CLN3 disease (juvenile neuronal ceroid lipofuscinosis). In: Morava E, Baumgartner M, Patterson M, Rahman S, Zschocke J, Peters V, eds. JIMD Reports. Berlin: Springer; 2018: 1-8.

59 Neverman NJ, Best HL, Hofmann SL, Hughes SM. Experimental therapies in the neuronal ceroid lipofuscinoses. Biochim Biophys Acta 2015; 1852: 2292-300.

60 Whiting RE, Narfstrom K, Yao G, et al. Enzyme replacement therapy delays pupillary light reflex deficits in a canine model of late infantile neuronal ceroid lipofuscinosis. Exp Eye Res 2014; 125: 164-72.

61 Whiting RE, Pearce JW, Castaner LJ, et al. Multifocal retinopathy in Dachshunds with CLN2 neuronal ceroid lipofuscinosis. Exp Eye Res 2015; 134: 123-32.

62 Worgall S, Sondhi D, Hackett NR, et al. Treatment of late infantile neuronal ceroid lipofuscinosis by CNS administration of a serotype 2 adeno-associated virus expressing CLN2 cDNA. Hum Gene Ther 2008; 19: 463-74.

63 Tamaki SJ, Jacobs Y, Dohse M, et al. Neuroprotection of host cells by human central nervous system stem cells in a mouse model of infantile neuronal ceroid lipofuscinosis. Cell Stem Cell 2009; 5: 310-19.

64 Cairo MS, Tarek N, Lee DA, Delaney C. Cellular engineering and therapy in combination with cord blood allografting in pediatric recipients. Bone Marrow Transplant 2016; 51: 27-33.

65 Yoon DH, Kwon OY, Mang JY, et al. Protective potential of resveratrol against oxidative stress and apoptosis in Batten disease lymphoblast cells. Biochem Biophys Res Commun 2011; 414: 49-52.

66 Sarkar C, Chandra G, Peng S, Zhang Z, Liu A, Mukherjee AB. Neuroprotection and lifespan extension in Ppt1(-/-) mice by NtBuHA therapeutic implications for INCL. Nat Neurosci 2013; 16: 1608-17.

67 Kinarivala N, Trippier PC. Progress in the development of small molecule therapeutics for the treatment of neuronal ceroid lipofuscinoses (NCLs). J Med Chem 2016; 59: 4415-27.

68 Hersrud SL, Kovacs AD, Pearce DA. Antigen presenting cell abnormalities in the Cln $3(-/-)$ mouse model of juvenile neuronal ceroid lipofuscinosis. Biochim Biophys Acta 2016; 1862: 1324-36.

69 Seehafer SS, Ramirez-Montealegre D, Wong AM, et al. Immunosuppression alters disease severity in juvenile Batten disease mice. J Neuroimmunol 2011; 230: 169-72.

70 Drack AV, Mullins RF, Pfeifer WL, Augustine EF, Stasheff SF, Hong SD. Immunosuppressive treatment for retinal degeneration in juvenile neuronal ceroid lipofuscinosis (juvenile Batten disease). Ophthalmic Genet 2015; 36: 359-64.

71 Cialone J, Augustine EF, Newhouse N, et al. Parent-reported benefits of flupirtine in juvenile neuronal ceroid lipofuscinosis (Batten disease; CLN3) are not supported by quantitative data. J Inherit Metab Dis 2011; 34: 1075-81.

72 Santiago JA, Bottero V, Potashkin JA. Dissecting the molecular mechanisms of neurodegenerative diseases through network biology. Front Aging Neurosci 2017; 9: 166.

73 Sharma J, di Ronza A, Lotfi P, Sardiello M. Lysosomes and brain health. Annu Rev Neurosci 2018; 41: 255-76.

74 Chandrachud U, Walker MW, Simas AM, et al. Unbiased cell-based screening in a neuronal cell model of Batten disease highlights an interaction between $\mathrm{Ca} 2+$ homeostasis, autophagy, and CLN3 protein function. J Biol Chem 2015; 290: 14361-80.

75 Medina DL, Di Paola S, Peluso I, et al. Lysosomal calcium signalling regulates autophagy through calcineurin and TFEB. Nat Cell Biol 2015; 17: 288-99.

76 Settembre C, Fraldi A, Medina DL, Ballabio A. Signals from the lysosome: a control centre for cellular clearance and energy metabolism. Nat Rev Mol Cell Biol 2013; 14: 283-96. 
77 Spampanato C, Feeney E, Li L, et al. Transcription factor EB (TFEB) is a new therapeutic target for Pompe disease. EMBO Mol Med 2013; 5: 691-706.

78 Palmieri M, Pal R, Nelvagal HR, et al. mTORC1-independent TFEB activation via Akt inhibition promotes cellular clearance in neurodegenerative storage diseases. Nat Commun 2017; 8: 14338.

79 Bajaj L, Lotfi P, Pal R, di Ronza A, Sharma J, Sardiello M. Lysosome biogenesis in health and disease. J Neurochem 2018; published online Aug 9. DOI:10.1111/jnc.14564.

80 Lotfi P, Tse DY, Di Ronza A, et al. Trehalose reduces retinal degeneration, neuroinflammation and storage burden caused by lysosomal hydrolase deficiency. Autophagy 2018; 14: 1419-34.

81 Ghosh A, Corbett GT, Gonzalez FJ, Pahan K. Gemfibrozil and fenofibrate, Food and Drug Administration-approved lipid-lowering drugs, up-regulate tripeptidyl-peptidase 1 in brain cells via peroxisome proliferator-activated receptor alpha: implications for late infantile Batten disease therapy. J Biol Chem 2012; 287: 38922-35.

82 Ghosh A, Jana M, Modi K, et al. Activation of peroxisome proliferator-activated receptor alpha induces lysosomal biogenesis in brain cells: implications for lysosomal storage disorders. J Biol Chem 2015; 290: 10309-24.

83 Ghosh A, Rangasamy SB, Modi KK, Pahan K. Gemfibrozil, Food and Drug Administration-approved lipid-lowering drug, increases longevity in mouse model of late infantile neuronal ceroid lipofuscinosis. J Neurochem 2017; 141: 423-35.
84 Abtahi-Naeini B, Sadeghiyan H, Adibi N, Shokrollahi MR, Pourazizi M. Bullous dermatosis of childhood induced by gemfibrozil. J Res Med Sci 2015; 20: 207-08.

85 Barcenas M, Xue C, Marushchak-Vlaskin T, Scott CR, Gelb MH, Turecek F. Tandem mass spectrometry assays of palmitoyl protein thioesterase 1 and tripeptidyl peptidase activity in dried blood spots for the detection of neuronal ceroid lipofuscinoses in newborns. Anal Chem 2014; 86: 7962-68.

86 Khaledi H, Liu Y, Masi S, Gelb MH. Detection of infantile batten disease by tandem mass spectrometry assay of PPT1 enzyme activity in dried blood spots. Anal Chem 2018; published online Sept 11. DOI:10.1021/acs.analchem.8b03188.

87 Grimm D, Zolotukhin S. E Pluribus Unum: 50 years of research, millions of viruses, and one goal--tailored acceleration of AAV evolution. Mol Ther 2015; 23: 1819-31.

88 Kleine Holthaus S-M, Ribeiro J, Abelleira-Hervas L, et al.

Prevention of photoreceptor cell loss in a Cln6nclf mouse model of batten disease requires CLN6 gene transfer to bipolar cells. Mol Ther 2018; 26: 1343-53.

(C) 2018 Elsevier Ltd. All rights reserved. 